Research article

\title{
Linking ecosystem function and hydrologic regime to inform restoration of a forested peatland
}

\author{
Morgan L. Schulte ${ }^{\mathrm{a}, 1}$, Daniel L. McLaughlin ${ }^{\mathrm{a}, *}$, Frederic C. Wurster ${ }^{\mathrm{b}}$, Karen Balentine ${ }^{\mathrm{b}}$, \\ Gary K. Speiran ${ }^{c}$, W. Mike Aust ${ }^{\mathrm{a}}$, Ryan D. Stewart ${ }^{\mathrm{d}}$, J. Morgan Varner ${ }^{\mathrm{e}}$, C. Nathan Jones ${ }^{\mathrm{f}}$ \\ ${ }^{a}$ Virginia Tech, Department of Forest Resources and Environmental Conservation, USA \\ ${ }^{\mathrm{b}}$ U.S. Fish and Wildlife Service, Great Dismal Swamp National Wildlife Refuge, USA \\ ${ }^{c}$ U.S. Geological Survey, Virginia Water Science Center, USA \\ ${ }^{\mathrm{d}}$ Virginia Tech, School of Plant and Environmental Sciences, USA \\ ${ }^{\mathrm{e}}$ U.S. Forest Service, Pacific Wildland Fire Sciences Laboratory, USA \\ ${ }^{\mathrm{f}}$ University of Maryland, The National Socio-Environmental Synthesis Center, USA
}

\section{A R T I C L E I N F O}

\section{Keywords:}

Forested wetlands

Peat

Red maple

Restoration

Disturbance

Great Dismal Swamp

\begin{abstract}
A B S T R A C T
Drainage is a globally common disturbance in forested peatlands that impacts peat soils, forest communities, and associated ecosystem functions, calling for informed hydrologic restoration strategies. The Great Dismal Swamp (GDS), located in Virginia and North Carolina, U.S.A., has been altered since colonial times, particularly by extensive ditch networks installed to lower water levels and facilitate timber harvests. Consequently, peat decomposition rates have accelerated, and red maple has become the dominant tree species, reducing the historical mosaic of bald cypress, Atlantic white-cedar, and pocosin stands. Recent repair and installation of water control structures aim to control drainage and, in doing so, enhance forest community composition and preserve peat depths. To help inform these actions, we established five transects of 15 plots each (75 plots total) along a hydrologic gradient where we measured continuous water levels and ecosystem attributes, including peat depths, microtopography, and forest composition and structure. We found significant differences among transects, with wetter sites having thicker peat, lower red maple importance, greater tree density, and higher overall stand richness. Plot-level analyses comported with these trends, clearly grouping plots by transects (via nonmetric multidimensional scaling) and resulting in significant correlations between specific hydrologic metrics and ecosystem attributes. Our findings highlight hydrologic controls on soil carbon storage, forest structure, and maple dominance, with implications for large-scale hydrologic restoration at GDS and in other degraded forested peatlands more broadly.
\end{abstract}

\section{Introduction}

\subsection{Hydrologic alteration in peatlands}

Peatlands occur globally in boreal, tropical/subtropical, and temperate regions, where they provide important ecosystem services (Kimmel and Mander, 2010) but are vulnerable to degradation and drainage (Holden et al., 2004). Peatland ecosystems vary within and across regions, ranging from Sphagnum-dominated to forested (or swamp) systems (Ott and Chimner, 2016). While peatlands only cover about 3\% of the Earth's land surface (Turetsky et al., 2015), they store $30 \%$ of global land carbon (Parish et al., 2008). Peatlands also regulate landscape nutrient budgets (e.g., phosphorus retention; Graham et al.,
2005) and hydrologic regimes (e.g., buffering downgradient streamflows; Holden et al., 2004). Despite their functional importance, peatlands of all types and across regions are at risk to hydrologic disturbance via drainage for land use and conversion (Usup et al., 2004; Watts and Kobziar, 2013).

In response to widespread degradation, peatland restoration efforts have expanded from the historical focus on Sphagnum-dominated bogs and fens to the full range of peatland types, including forested peatlands (Chimner et al., 2017). Hydrologic regimes exert large controls on both peat depths (Beylea and Bair, 2006) and forested community development (sensu van der Valk, 1981). As such, "rewetting" (e.g., damming or filling in ditches) is a focal strategy of forested peatland restoration aimed at sustained carbon storage and recovery of historical vegetation

\footnotetext{
* Corresponding author.

E-mail address: mclaugd@vt.edu (D.L. McLaughlin).

${ }^{1}$ Now at: North Carolina State University, Forest Productivity Cooperative.
} 


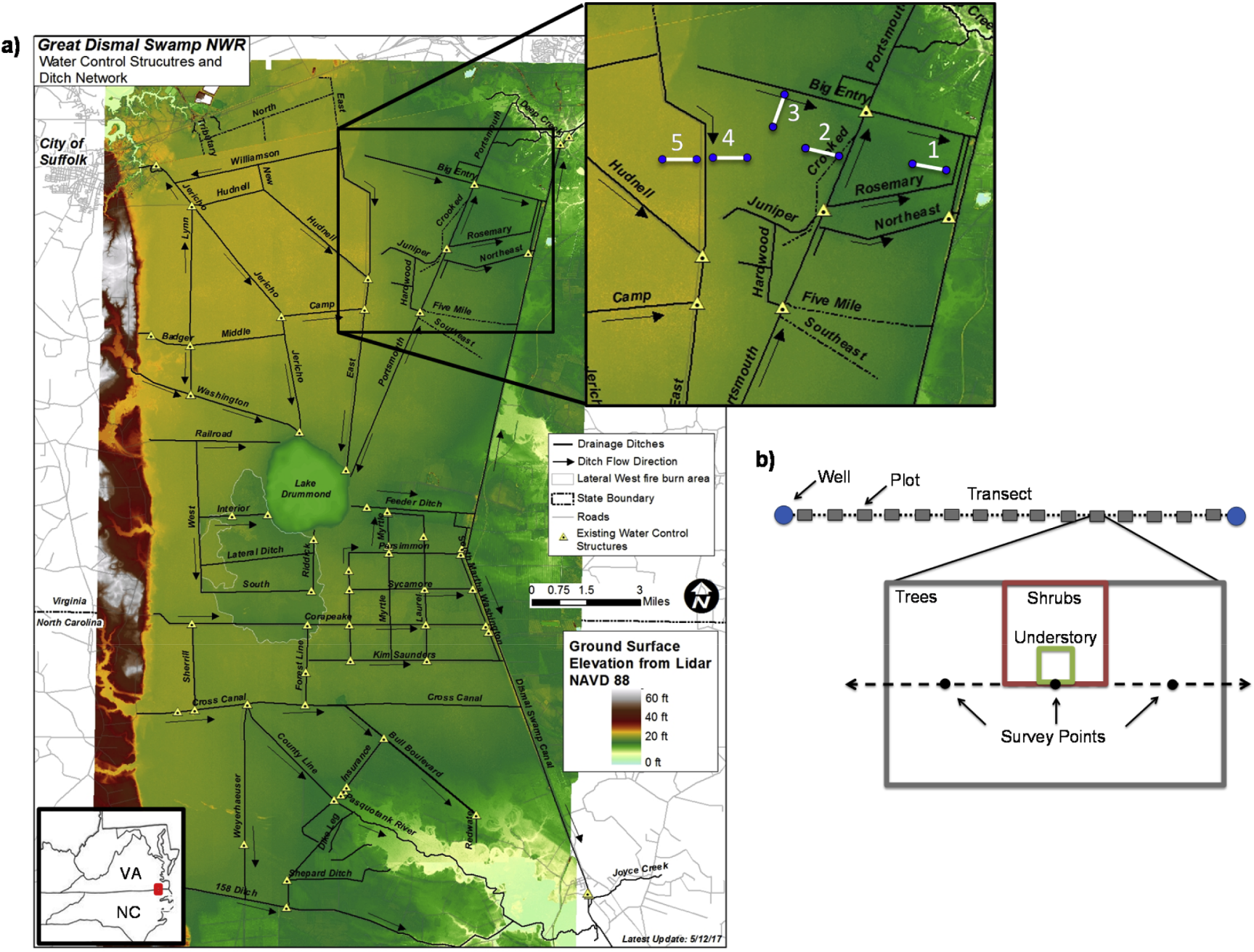

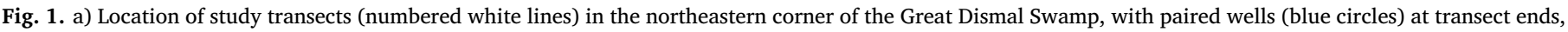

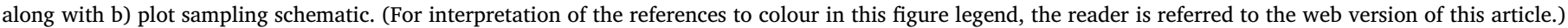

communities (Chimner et al., 2017). However, specific hydrologic influences can vary across regions and systems, highlighting the importance of monitoring to inform restoration. In this work, we focused on the forested peatlands of the Great Dismal Swamp (GDS), exploring empirical linkages between contemporary hydrologic regimes and forested wetland communities. Our overarching objective was to help guide restoration strategies at GDS while also informing coupled monitoring and management efforts at other degraded forested peatlands more broadly.

The GDS is a large expanse of forested wetlands in southeastern Virginia and northeastern North Carolina that has been substantially altered (Fig. 1). GDS once extended approximately 500,000 ha (Osbon, 1919) and was characterized by a mosaic of forested wetland communities (Legrand, 2000). From the late 1700s-1970s, the GDS landscape was ditched and drained to make it accessible for timber harvesting (see Fig. 1), resulting in lowered water tables (Levy, 1991; Legrand, 2000), altered forest community composition (Phipps et al., 1979), and increased peat soil decomposition rates and fire vulnerability (Whitehead and Oaks, 1979; Reddy et al., 2015). In response, the GDS National Wildlife Refuge has installed or repaired water control structures (i.e., dam-like structures with adjustable barriers) at 49 locations in the $240 \mathrm{~km}$ ditch network to better manage hydrologic regimes, maintain peat soil depths, and restore historical forest communities across GDS. This research aims to inform these large-scale restoration efforts by assessing hydrologic controls on ecosystem structure and function.

\subsection{Hydrologic controls on peat soils}

Peat accumulation in forested wetlands provides multiple functions, from carbon storage (Clymo et al., 1988) to microtopographic-induced complexity in habitat and forest composition (Vivian-Smith, 1997). Hydrologic regime (mean and variation in water levels) exerts strong, long-term controls on peat accretion, with prolonged inundated or saturated conditions greatly reducing microbial decomposition. However, accretion rates are slow $(0.3-6 \mathrm{~mm} / \mathrm{yr}$; Whitehead and Oaks, 1979; Craft and Richardson, 1993; Drexler et al., 2017), meaning current peat depths largely reflect historical rather than contemporary hydrologic regimes. Yet, reductions in contemporary water levels amplify both decomposition rates (Wosten et al., 1997; Wust-Galley et al., 2016) and fire vulnerability (Turetsky et al., 2015), and can lead to attendant losses of historical peat deposits and carbon storage (Reddy et al., 2015). Hydrologic regimes also influence spatial structure in local peat elevations, with associated effects on vegetation composition. High water levels in forested peatlands favor formation of variable microtopography (Ehrenfeld, 1995a) through several mechanisms, including differential peat accumulation, root growth, and often windthrow due to shallow rooting depths (Golet et al., 1993; Bruland and Richardson, 2005). This microtopography creates spatial variation in hydrologic regimes, where the spatial suite of resulting hydroperiods increases habitat complexity and stand-level diversity in vegetation (VivianSmith, 1997). 
At GDS, peat soils began accumulating about 9000 years ago due to clay-rich confining layers and low topographic relief that promoted constant saturation and flooding (Whitehead, 1972). Prior to disturbance, peat depths ranged from approximately $1 \mathrm{~m}-5 \mathrm{~m}$ (Osbon, 1919; Lewis and Cocke, 1929) and generally reflected topographic variation of the sand strata underlying the peat, with maximum accumulation occurring within paleo-stream valleys and minimum accumulation on their surrounding uplands (Lichtler and Walker, 1974). However, ditching lowered contemporary water levels, dried surface peat, and increased peat oxidation. Past estimates of peat subsidence suggest an average of $1 \mathrm{~m}$ of organic soil loss since ditching (ca. $3 \mathrm{~mm} /$ year; Whitehead and Oaks, 1979). Continued subsidence since these records likely still occurs, as evidenced by exposed tree roots. Lowered water levels have also increased smoldering fire risk and associated peat loss (Reddy et al., 2015). Peat thickness at GDS now ranges from only $0.3 \mathrm{~m}-4 \mathrm{~m}$ (Reddy et al., 2015), with an observed local microtopographic variation of $0.21-0.36 \mathrm{~m}$ in surface elevation (Levy and Walker, 1979). Preserving existing peat depths and associated carbon storages and increasing peat accumulation rates are important management goals at GDS. Thus, in this work we sought to link current hydrologic regimes and peat depths, with the expectation that wetter conditions will preserve peat depths and enhance microtopographic variation.

\subsection{Hydrologic controls on vegetation composition}

Wetland vegetation composition is largely driven by spatial and temporal dynamics of water level variation (Mitsch and Gosselink, 2007). In forested wetlands altered by ditching, the resulting lowered water levels often favor aggressive facultative tree species over obligate wetland species, especially during regeneration (Legrand, 2000; Atkinson et al., 2003). In addition, other disturbances (e.g., timber harvest) often associated with hydrologic manipulation can exert large influences to forest composition, where resultant communities are the products of multiple ecological sieves: remnant individuals; dispersal and regeneration requirements; and hydrologic regimes (sensu van der Valk, 1981).

Across GDS, both hydrologic alteration and past selective timber harvest have influenced forest development, where growth, mortality, and regeneration of post-harvest forests are likely influenced by contemporary hydrologic regimes. Historically, GDS was a mosaic of forested wetland communities, including bald cypress/tupelo (Taxodium/Nyssa spp.), Atlantic white-cedar (Chamaecyparis thyoides, hereafter "cedar"), and pond pine (Pinus serotina) stands. However, GDS wetlands are now dominated by an overstory of red maple (Acer rubrum; a facultative species) and a mixed midstory composition that varies based on local hydrology (Legrand, 2000; Sleeter et al., 2017). Atlantic white cedar (Chamaecyparis thyoides, hereafter "cedar") swamps, estimated to once cover 26,000-45,000 ha in the GDS (Frost, 1987), occurred on only 6\% of GDS area, or 2700 ha, as of 2003 (DeBerry and Atkinson, 2014). Together, tupelo, bald cypress, and pond pine communities make up less than half of current GDS forest cover, compared to their dominant historical coverage (Levy, 1991). We expect that hydrologic alteration is, in part, responsible for the reduced spatial extent of these communities, where drier sites are now dominated by red maple and with lower species richness. Although many studies of GDS forest communities have been conducted over the past four decades (e.g., Dabel and Day Jr, 1977; Levy, 1991; Carter et al., 1994; Legrand, 2000), linkages between contemporary hydrologic regimes and species composition are implied but not well understood.

To better understand current hydrologic controls on ecosystem structure and function in GDS, we explored empirical relationships between hydrologic regime and ecosystem attributes, specifically peat depths, microtopography, and vegetation composition. We hypothesized (H1) that higher and more stable water levels would preserve peat depths and microtopography. We also hypothesized (H2) that red maple would be less competitive at higher mean water levels, thus increasing stand richness at wetter sites. To test these hypotheses, we measured ecosystem attributes and water levels across locations with varying hydrologic regime. This research has direct implications on the restoration activities at GDS and more broadly in other degraded forested peatlands (Chimner et al., 2017).

\section{Materials and methods}

\subsection{Study site}

GDS is an expansive forested palustrine wetland extending 45,000 ha in southeastern Virginia and northeastern North Carolina, USA. The climate is temperate with long, humid summers and mild winters. Mean annual precipitation is $1180 \mathrm{~mm}$ (1981-2010; NOAA). The dominant forest cover type is red maple-gum, characterized as red maple dominated with co-occurring Nyssa spp. (Gammon and Carter, 1979; Levy, 1991; Sleeter et al., 2017). Although soils at GDS are generally considered fibric peat, soil types vary spatially and include sapric peats and mineral soils (NRCS Web Soil Survey).

Sites were located in the northeastern corner of the Great Dismal Swamp National Wildlife Refuge (Fig. 1) in coordination with a hydrologic monitoring network previously established by the Refuge and U.S. Geological Survey (USGS). Our study began in 2015 and concluded prior to the installation of 12 water control structures in this portion of the refuge in 2016 and 2017. As such, data presented here characterize baseline conditions for hydrologic regimes and ecosystem attributes before any intentional hydrologic change. We selected five sites to capture a gradient in hydrologic regimes based on synoptic surveys of water depth and wetness indicators. At each of the five sites, we established one $300 \mathrm{~m}$ transect perpendicular to a corresponding ditch or road (Fig. 1). Along each transect, we established fifteen plots, spaced at $20 \mathrm{~m}$ intervals (Fig. 1b), to measure: hydrologic regime, land surface elevation, peat depths, and vegetation attributes. Plots $(n=75)$ captured a wetness gradient both within and across transects due to topography and varying distances from roads or ditches. Collected well data (below), as opposed to our synoptic and qualitative observations, were used to characterize and quantify differences in hydrologic regimes at both plot and transect-scales.

\subsection{Data collection}

To estimate hydrologic regime at each plot, we related continuous measures of water level elevation to plot land surface elevations across each transect. Monitoring wells were installed at each end of transects by GDS and USGS staff ( $n=2$ per transect; Fig. 1a and b). Vented submersible pressure transducers (Campbell Scientific CS 450, In-Situ Level Troll 500, and KPSI 500) in each well provided continuous 15min water level data for 16 months (April 2015-July 2016), prior to any hydrologic restoration efforts at the site. We surveyed well elevations and ground elevations of plot centers and $3 \mathrm{~m}$ in either transect direction from plot centers (Fig. 1b) using an optical level and differential levelling techniques outlined in Kenney (2010). A microtopographic index was calculated for each plot as the standard deviation of the three elevation points per plot. Using our surveyed elevations and water level data at each well, we interpolated to estimate 15-min water level height (relative to ground surface) at each of the three surveyed locations in each plot. This approach yielded spatial (three locations per plot) and temporal water level variation at each plot to explore relationships among hydrology, peat depth, microtopography, and vegetation across all 75 plots. Our interpolation of well data assumes a linear slope for water surface across the $300 \mathrm{~m}$ transects. Such an assumption is valid for inundated conditions across an entire transect (i.e., constant water elevation for lentic systems) but may induce errors for partially inundated transects where a sloping water surface is applied to both flooded and non-flooded locations. Errors may also be introduced for belowground water levels due to possible non-linear 
gradients in water surface near drainage ditches. Such drawdown is expected within $20 \mathrm{~m}$ of drainage ditches (Boelter, 1972) or when the water table occurs within deeper, more decomposed peats with low hydraulic conductivity (Lichtler and Walker, 1974). However, such errors are expected to be minimized over the $300 \mathrm{~m}$ transect distance.

Peat and vegetation surveys were conducted in summer 2015. Peat depth was measured at plot center using a soil probe, which was handpushed down through the peat until resistance was felt from underlying mineral soil. To characterize vegetation composition, each plot included three nested subplots established from plot center to measure vegetation at different strata: tree, shrub, and understory (Fig. 1b). In the tree plot $(10 \times 6 \mathrm{~m})$, diameter at breast height $(\mathrm{dbh})$ and species were recorded for each tree $(>2.54 \mathrm{~cm} \mathrm{dbh})$. In the shrub plot $(3 \times 3 \mathrm{~m})$, species and ground line basal diameter were recorded for each stem $(<2.54 \mathrm{~cm}$ and $>33 \mathrm{~cm}$ tall $)$. In the understory plot $(1 \times 1 \mathrm{~m})$, percent cover for all herbaceous and woody species $(<33 \mathrm{~cm}$ tall) was recorded by species using an ocular $0-5$ groundcover scale (Daubenmire, 1959). Seedlings were also tallied by species in the understory plots.

\subsection{Data analysis}

We characterized hydrologic regime at both transect and plot level. Plot mean water levels were calculated as the average of estimated 15min water levels across the three plot surveyed locations. We also calculated 10th (low water levels) and $90^{\text {th }}$ (high water levels) percentiles and temporal standard deviation for each plot using the 15-min water level data. Transect mean water levels were calculated as the average of the 15 plot means associated with each transect. Transectscale 10 th and $90^{\text {th }}$ percentiles and temporal standard deviations were also calculated using 15-min water levels from all 15 plots.

We calculated several metrics to characterize vegetation attributes in each plot and within transects (mean of plot metrics) and separately for tree, shrub, and understory strata. For tree and shrub strata, we calculated stem density and basal area (total and by species). To better understand the presence of red maple in the tree stratum, we calculated relative maple stem density (sum of maple stem density/sum of total density), relative maple basal area (sum of species basal area/sum of total basal area), and red maple Importance Value as the sum of these two values (represented as a percent of maximum value). For understory, we calculated plot frequency of obligate wetland species and seedling density (total and by species). Lastly, we used count of species present across all strata to determine overall stand richness for each plot.

To evaluate relationships between hydrologic regime and ecosystem attributes, we performed three different analyses, allowing us to explore influences of hydrologic variation at both stand (i.e., transect) and within-stand (i.e., plot) spatial scales. First, we performed a transectlevel categorical analysis using a Kruskal-Wallis H test $(\alpha=0.05)(R$
Core Team, 2016) to assess transect differences in water level metrics, peat depth, microtopographic index, and vegetation metrics. When a significant difference was detected, we used a Wilcoxon rank sum test to evaluate pair-wise differences between transects. To infer hydrologic influences, we assessed consistencies in transect differences for both hydrologic regimes and ecosystem attributes. We further evaluated differences among stands at the transect scale via tree size class distributions and quadratic mean tree diameters (QMD; Curtis and Marshall, 2000). Second, at the plot-scale, we utilized a nonmetric multidimensional scaling (NMDS) ordination analysis to explore plotlevel variation across measured ecosystem attributes and associated variation in hydrologic parameters using the 'vegan' package within the R statistical software environment (Oksanen et al., 2017; R Core Team, 2016). Plot-level ecosystem attributes (vegetation metrics, microtopographic index, and peat depth) were used to develop the NMDS model, whereas hydrologic parameters were not included in the model but were analyzed for associated variation within the model ordination space. To develop the model, we used: Euclidean distance of scaled ecosystem attribute parameters as the dissimilatory measure; 10,000 model iterations to ensure avoidance of local minima and maxima; and dimensionality of ordination space and stress (i.e., goodness-of-fit to represent deformation of data when transformed into ordination space) to select the number of ordination axes (Kruskal, 1964; Clarke, 1993). Then, linear environmental vectors were fit using least-square optimization to explore variation of both ecosystem and hydrologic parameters across ordination space. Lastly, we separately explored plotlevel correlations (via Spearman's correlation analysis) among hydrologic regime metrics, vegetation attributes, microtopographic index, and peat depth across all 75 plots as a more robust and quantitative assessment of hydrologic controls.

\section{Results}

We evaluated hydrologic influences on peat soils (depth and microtopography; H1) and vegetation attributes (H2) at two different spatial scales: transect and plot. Below, we first present assessments of hydrologic variation at both scales and then separately assess transectand plot-level relationships between hydrologic regime and ecosystem attributes.

\subsection{Transect- and plot-level hydrology}

Hydrologic regimes were markedly different among transects, allowing us to characterize sites from dry (transect 1 ) to wet (transect 5). Transect mean water level ranged from $-0.58 \mathrm{~m}$ (i.e., below land surface) at transect 1 to $0.16 \mathrm{~m}$ at transect 5 , with significant $(\mathrm{P}<0.05)$ pairwise differences between all transects (Fig. 2a). Note that while Transect 5 is at a higher elevation compared to other transects (Fig. 1a), it has the wetter regime likely due to a nearby road

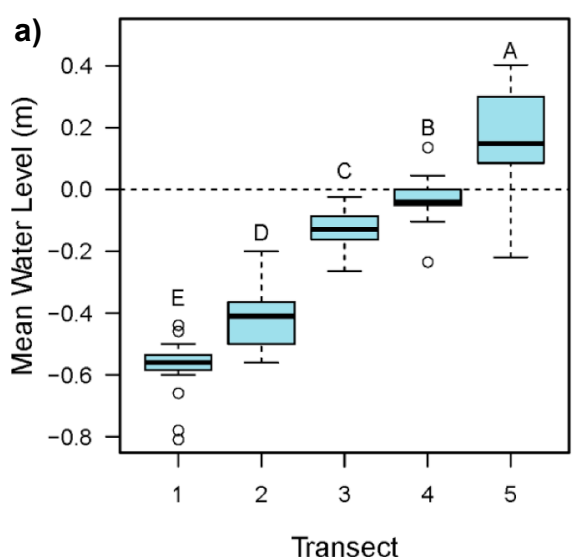

Transect

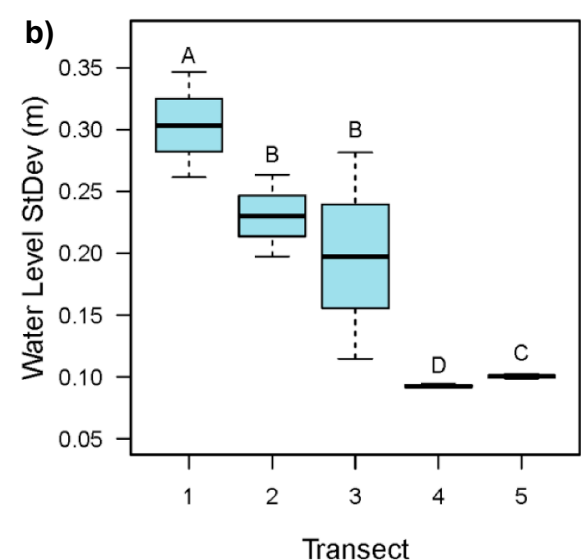

Fig. 2. Box plots by transect for plot a) mean water level and b) temporal standard deviation in water level. Dashed line denotes ground surface. Letters denote significant pair-wise differences $(P<0.05)$ between transects using Wilcoxon Rank Sum Test. (For interpretation of the references to colour in this figure legend, the reader is referred to the web version of this article.) 
acting as an impoundment and a lower ditch density. Temporal water level standard deviation at the transect-level highlighted significant differences in water level variation across all transects except between transects 2 and 3 (Fig. 2b). Similar trends across transects (driest to wettest transect; 1 to 5 ) were also found for 10 th ( -0.97 to $0.01 \mathrm{~m}$ ) and $90^{\text {th }}$ percentiles ( -0.33 to $0.24 \mathrm{~m}$ ), revealing significant transect differences for both low and high water-level conditions, respectively $(\mathrm{P}<0.05)$.

Box-plot distributions of plot mean water level and standard deviations (Fig. 2) also illustrate differences in hydrologic regime at the plot level both within and across transects. Plot mean water level ranged from $-0.81 \mathrm{~m}$ (minimum plot value at transect 1) to $0.40 \mathrm{~m}$ (maximum at transect 5; Fig. 2a); standard deviation ranged from $0.35 \mathrm{~m}$ to $0.09 \mathrm{~m}$ (Fig. $2 \mathrm{~b}$ ). Water level 10th and $90^{\text {th }}$ percentiles ranged from $-1.33 \mathrm{~m}$ to $0.32 \mathrm{~m}$ and $-0.55 \mathrm{~m}$ to $0.55 \mathrm{~m}$, respectively. All hydrologic parameters significantly covaried with each other $(\mathrm{P}<0.05$, data not shown). The wettest plots (via mean water level) had the lowest water level variation (i.e., standard deviation) and highest 10th and $90^{\text {th }}$ percentiles. Lastly, estimated water levels suggest that 39 plots were never flooded, 25 were intermittently flooded, and 11 were permanently flooded.

\subsection{Transect-level relationships between hydrologic regime and ecosystem attributes}

Mean peat depths ranged from $59 \mathrm{~cm}$ to $134 \mathrm{~cm}$ and increased significantly with transect wetness (from transect 1 to 5; Fig. 3a). Microtopographic index values demonstrated elevation (and thus hydrologic) variation within transects and were significantly different among all transects, with the highest values at the wettest two transects (Fig. 3b).

Vegetation composition and structure also varied across transects. Frequencies of obligate and facultative wetland tree species (e.g., swamp tupelo, sweetbay) increased with transect wetness (Fig. 4; Table 1); however, red maple occurred at all transects and across all size classes. Tree size class distributions also varied, with increasing frequencies of small diameter trees and concordant decreasing QMD with increasing wetness (Fig. 4). Tree densities were significantly higher at transects 4 and 5 (the two wettest transects), but relative density of red maple was highest at the three driest transects $(\mathrm{P}<0.05$, Fig. 5a). Tree basal area showed no significant trend with wetness, whereas relative basal area for red maple was highest at the three driest transects $(\mathrm{P}<0.05$; Fig. 5b). Consequently, red maple importance in the tree stratum was lower at the two wettest transects (Fig. 5c). There were no significant trends in shrub metrics with increased transect wetness, and red maple contributed very little (ca. 1\%) to shrub density in all transects (Fig. 5d; Table 1). Although there was no significant trend for seedling metrics, total and maple seedling densities were generally higher at the wettest transects (Fig. 5e). The

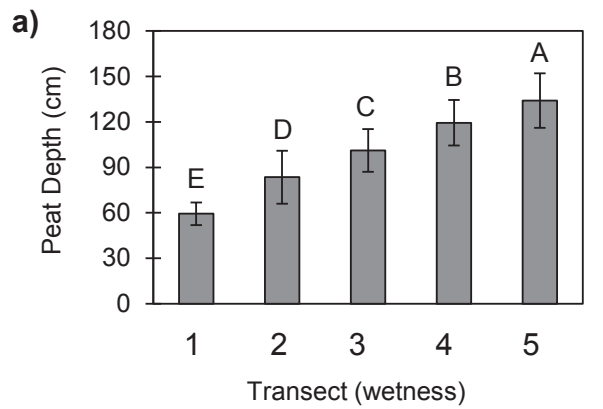

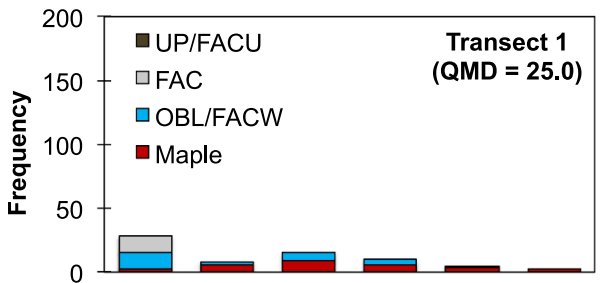
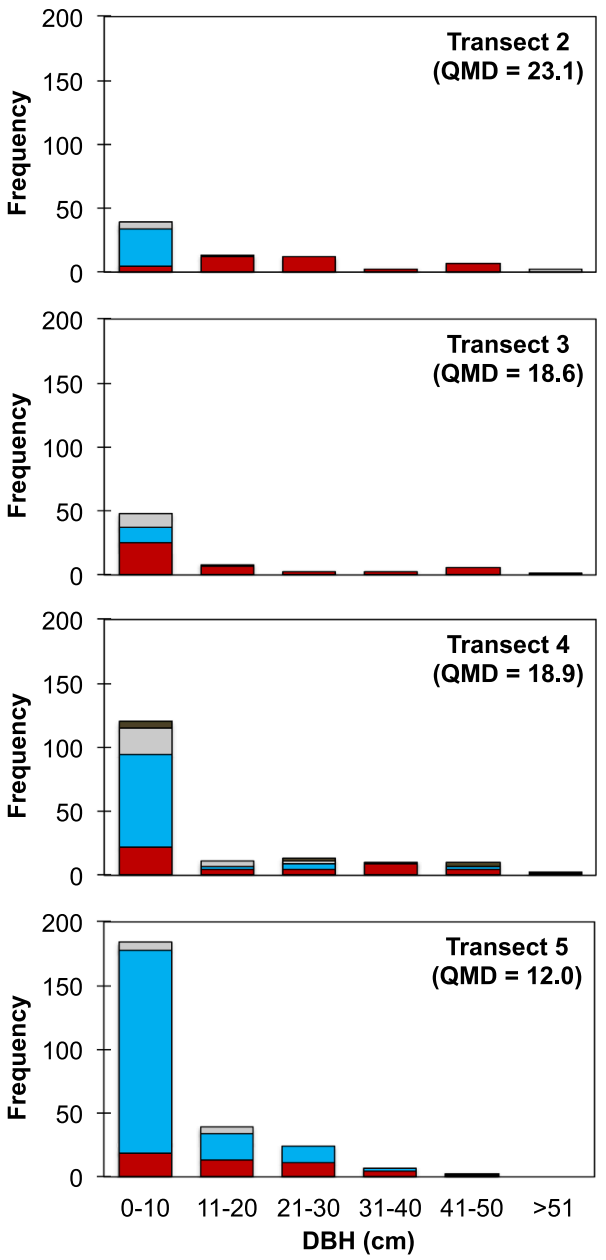

Fig. 4. Quadratic mean diameter (QMD) and tree size class distributions (by DBH) for each transect. Species frequencies by wetland class are also shown (see categories in Table 1). (For interpretation of the references to colour in this figure legend, the reader is referred to the web version of this article.)

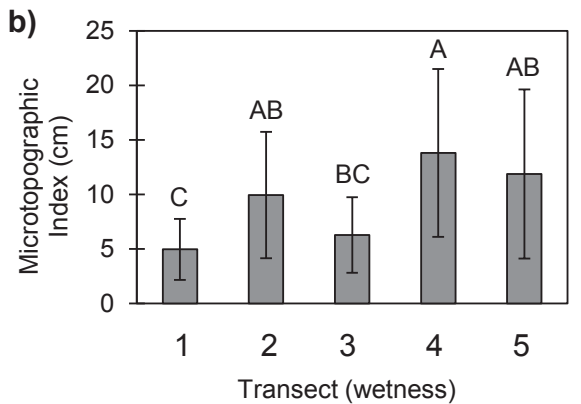

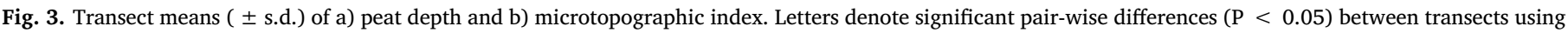
Wilcoxon Rank Sum Test. (For interpretation of the references to colour in this figure legend, the reader is referred to the web version of this article.) 
Table 1

List of most commonly observed species with percentage of plots per transect where species occurred. Species are classified using the Atlantic and Gulf Coastal Plain (AGCP) Regional Wetland Plant List Classification: upland (UPL), facultative upland (FACU), facultative (FAC), facultative wetland (FACW), and obligate wetland (OBL).

\begin{tabular}{|c|c|c|c|c|c|c|c|}
\hline \multirow[t]{2}{*}{ Common Name } & \multirow[t]{2}{*}{ Scientific Name } & \multirow[t]{2}{*}{ AGCP } & \multicolumn{5}{|c|}{ Frequency (Percent of Plots) } \\
\hline & & & 1 & 2 & 3 & 4 & 5 \\
\hline \multicolumn{8}{|l|}{ Tree } \\
\hline Tulip-poplar & Liriodendron tulipifera $\mathrm{L}$. & FACU & 0 & 0 & 0 & 33 & 0 \\
\hline Red maple & Acer rubrum $\mathrm{L}$. & FAC & 93 & 100 & 80 & 80 & 87 \\
\hline Pawpaw & Asimina triloba $\mathrm{L}$. & FAC & 33 & 20 & 7 & 7 & 0 \\
\hline American holly & Ilex opaca Ait. & FAC & 0 & 7 & 20 & 60 & 47 \\
\hline Sweetgum & Liquidambar styraciflua L. & FAC & 0 & 7 & 20 & 0 & 0 \\
\hline Blackgum & Nyssa sylvatica Marsh. & FAC & 0 & 0 & 7 & 0 & 7 \\
\hline Sweetbay & Magnolia virginiana $\mathrm{L}$. & FACW & 7 & 13 & 13 & 33 & 33 \\
\hline Redbay & Persea borbonia L. & FACW & 13 & 47 & 33 & 87 & 100 \\
\hline Swamp Tupelo & Nyssa biflora Walt. & OBL & 40 & 0 & 0 & 13 & 67 \\
\hline \multicolumn{8}{|l|}{ Shrub } \\
\hline Red maple & Acer rubrum $\mathrm{L}$. & FAC & 0 & 7 & 33 & 60 & 13 \\
\hline Greenbriar & Smilax spp & FAC & 33 & 20 & 93 & 87 & 73 \\
\hline Giant cane & Arundinaria gigantea Walt. & FACW & 0 & 0 & 93 & 80 & 40 \\
\hline Sweet pepperbush & Clethra alnifolia L. & FACW & 100 & 100 & 0 & 0 & 0 \\
\hline H. blueberry & Vaccinium corymbosum $\mathrm{L}$. & FACW & 0 & 0 & 33 & 27 & 60 \\
\hline \multicolumn{8}{|l|}{ Understory } \\
\hline Virginia creeper & Parthenocissus quinquefolia $\mathrm{L}$. & FACU & 27 & 0 & 0 & 0 & 0 \\
\hline Muscadine grape & Vitis rotundifolia Michx. & FAC & 33 & 33 & 20 & 0 & 0 \\
\hline Poison ivy & Toxicodendron radicans $\mathrm{L}$. & FAC & 7 & 13 & 33 & 7 & 0 \\
\hline Sphagnum moss & Sphagnum spp & OBL & 0 & 0 & 0 & 27 & 20 \\
\hline Bladderwort & Utricularia spp & OBL & 0 & 0 & 0 & 0 & 67 \\
\hline Netted chain fern & Woodwardia areolata $\mathrm{L}$. & OBL & 13 & 0 & 0 & 0 & 0 \\
\hline V. chain fern & Woodwardia virginica $\mathrm{L}$. & OBL & 0 & 7 & 13 & 0 & 0 \\
\hline
\end{tabular}

a)

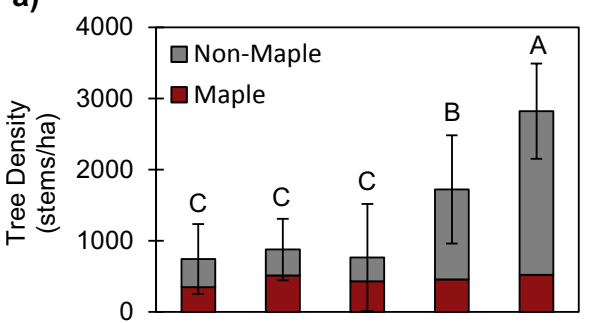

b)

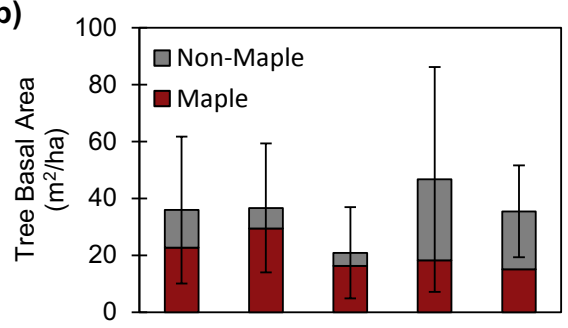

c)

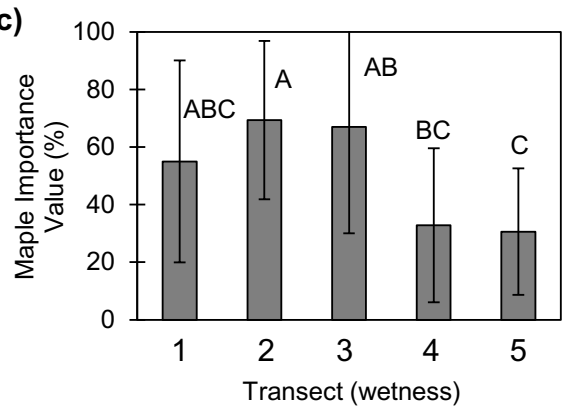

d)

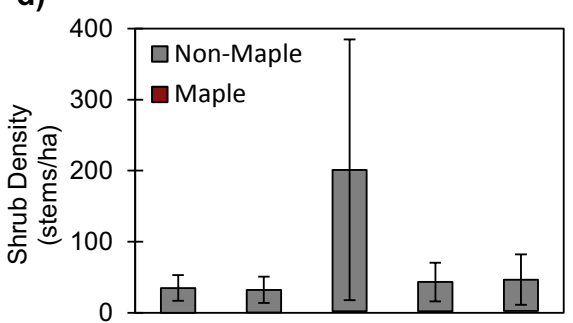

e)

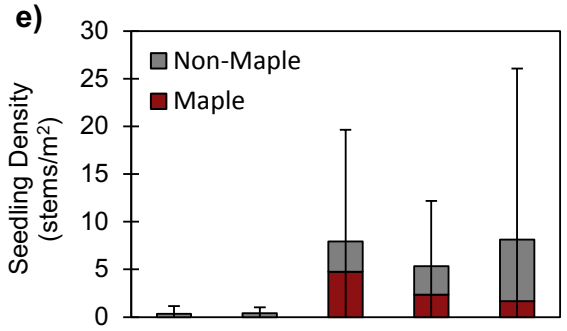

f)

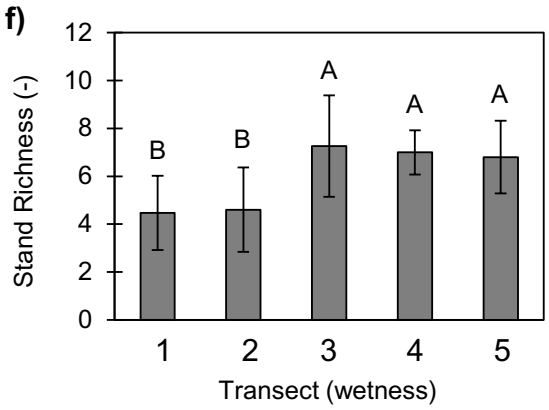

Fig. 5. Transect means ( \pm s.d.) of a) tree density, b) tree basal area, c) maple tree importance value, d) shrub density, e) seedling density, and f) stand richness. Mean proportions of red maple for $(\mathrm{a}-\mathrm{b})$ and (d-e) are denoted in red. Letters denote significant pair-wise differences $(P<0.05)$ between transects using Wilcoxon Rank Sum Test. (For interpretation of the references to colour in this figure legend, the reader is referred to the web version of this article.) 


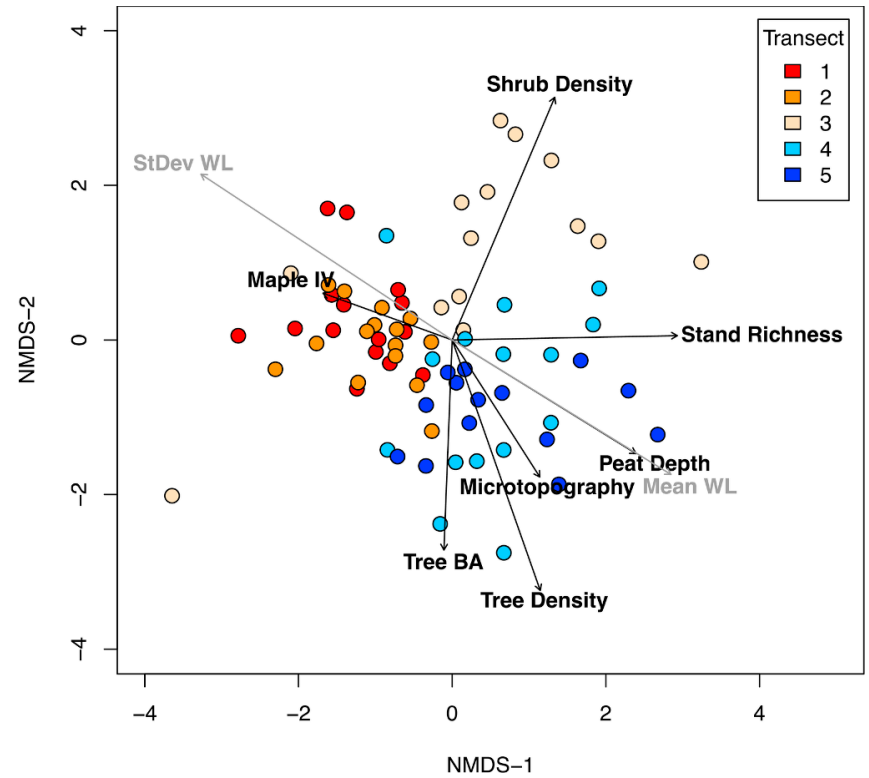

Fig. 6. Non-metric multidimensional scaling analysis (NMDS) of plot-level ecosystem attribute metrics along with vector analysis of those input parameters (in black) as well as non-input hydrologic parameters (mean and standard deviation of water level; shown in grey). The vector arrows show the direction of increasing parameter gradient in relation to the axes, where the vector length is proportional to the correlation between the parameter and axes. Plots are colored by transect. (For interpretation of the references to colour in this figure legend, the reader is referred to the web version of this article.)

occurrence of understory obligate wetland species also increased with transect wetness (Table 1). Lastly, across all strata, mean stand species richness ranged from 4.5 to 7.3 , and was significantly higher at the three wettest transects (Fig. 5f).

\subsection{Plot-level relationships between hydrologic regime and ecosystem attributes}

Dominant gradients in peat and vegetation metrics across all plots were identified using a nonmetric multidimensional scaling (NMDS) ordination analysis. We chose a two-axis NMDS model, which yielded both high correlation $\left(R^{2}=0.92\right)$ and relatively low stress $(S=0.17)$ of observed dissimilarity. Fig. 6 displays plot-level ecosystem attribute metrics in ordination space, where vectors represent significant variation in these ecosystem metrics along with covarying hydrologic metrics (shown in grey) across ordination space. Note that hydrologic metrics shown in Fig. 6 were not included in the NMDS model; thus, fitted vectors illustrate correlation between hydrologic variables and dominant gradients in ecosystem attributes. NMDS ordination space also illustrates both across and within transect variation, where the driest transect plots (transects 1 and 2) grouped together, as did the wettest transect plots (transects 4 and 5). Transect 3 plots, which had intermediate wetness, grouped out separately largely due to high shrub density. Increasing tree metrics (i.e., tree basal area, tree density) opposed shrub density. Notably, hydrologic metrics significantly explained variation in the ordination space, where increasing wetness negatively covaried with maple importance and positively covaried with peat depth, microtopography, and stand richness.

Correlation analysis further highlighted relationships between hydrologic metrics and ecosystem attributes. Supporting transect-level trends, peat depth had a strong positive correlation with mean water level (Fig. 7a) and a strong negative relationship with water level standard deviation (Table 2). Microtopographic index had a weak, but positive relationship with mean water level and a negative (but stronger) relationship with water level standard deviation (Table 2).
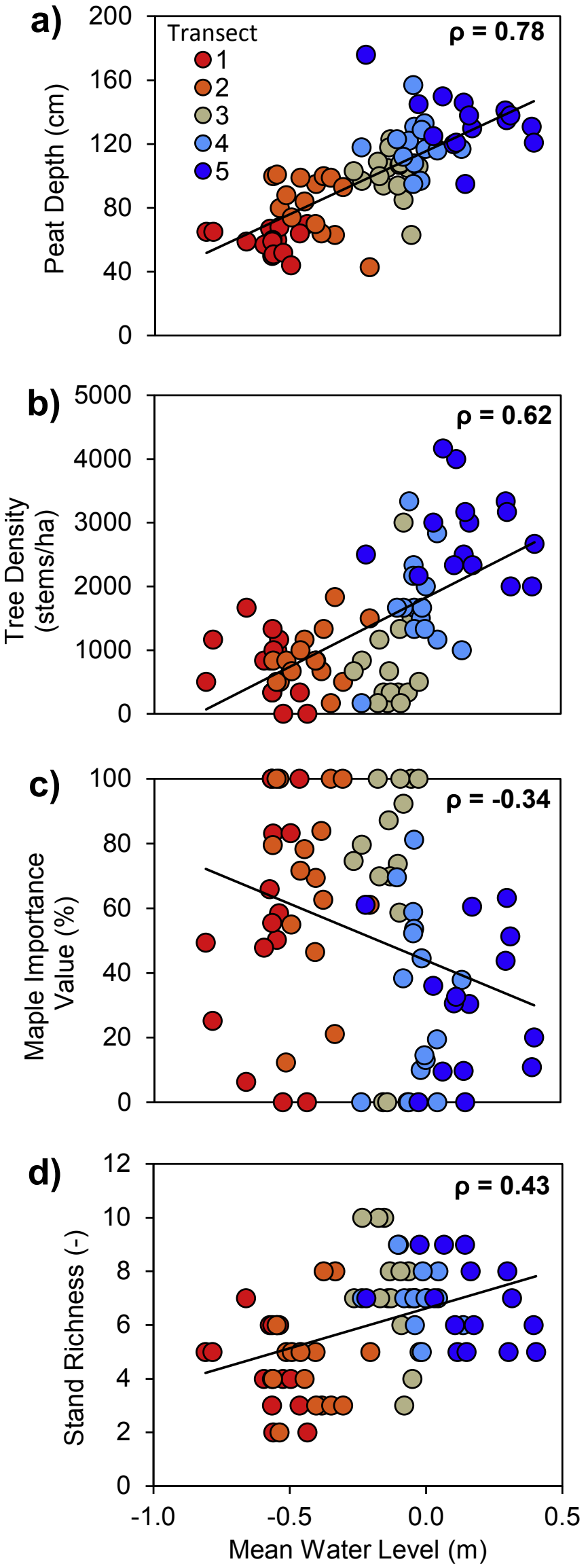

(caption on next page) 
Fig. 7. Plot-level a) peat depth, b) tree density, c) maple importance value, and d) stand richness vs. mean water level. Spearman's $\rho$ shown for correlations with significance of $\mathrm{P}<0.05$. Points are colored by transect. (For interpretation of the references to colour in this figure legend, the reader is referred to the web version of this article.)

Table 2

Spearman rank correlations between water level (WL) statistics and ecosystem attributes.

\begin{tabular}{lllll}
\hline & Mean WL & StDev WL & $10 \% \mathrm{WL}$ & $90 \% \mathrm{WL}$ \\
\hline Peat Depth & $\mathbf{0 . 7 8}$ & $-\mathbf{0 . 8 1}$ & $\mathbf{0 . 7 9}$ & $\mathbf{0 . 5 8}$ \\
Microtopographic Index & $\mathbf{0 . 2 7}$ & $-\mathbf{0 . 4 6}$ & $\mathbf{0 . 2 9}$ & 0.16 \\
Stand Species Richness & $\mathbf{0 . 4 3}$ & $-\mathbf{0 . 4 6}$ & $\mathbf{0 . 4 2}$ & $\mathbf{0 . 3 0}$ \\
Tree Density & $\mathbf{0 . 6 2}$ & $-\mathbf{0 . 5 1}$ & $\mathbf{0 . 5 8}$ & $\mathbf{0 . 5 0}$ \\
Tree Basal Area & 0.00 & -0.12 & 0.05 & 0.00 \\
Shrub Density & 0.12 & -0.09 & 0.07 & 0.00 \\
Seedling Density & $\mathbf{0 . 3 3}$ & $-\mathbf{0 . 4 1}$ & $\mathbf{0 . 2 8}$ & 0.10 \\
Maple Importance Value & $-\mathbf{0 . 3 4}$ & $\mathbf{0 . 3 0}$ & $-\mathbf{0 . 3 1}$ & -0.23 \\
Maple Tree Density & 0.09 & -0.06 & 0.11 & 0.14 \\
Maple Tree Relative Density & $-\mathbf{0 . 3 8}$ & $\mathbf{0 . 3 2}$ & $-\mathbf{0 . 3 4}$ & -0.26 \\
Maple Tree Basal Area & -0.19 & 0.06 & -0.12 & -0.15 \\
Maple Tree Relative Basal Area & $-\mathbf{0 . 3 2}$ & $\mathbf{0 . 3 0}$ & $-\mathbf{0 . 3 0}$ & -0.23 \\
Maple Seedling Density & $\mathbf{0 . 3 5}$ & $-\mathbf{0 . 4 1}$ & $\mathbf{0 . 3 1}$ & 0.17 \\
Maple Seedling Relative Density & $\mathbf{0 . 3 3}$ & $-\mathbf{0 . 3 9}$ & 0.31 & $\mathbf{0 . 1 9}$ \\
\hline
\end{tabular}

Bold values significant at $\mathrm{P}<0.05$.

Tree density significantly increased with mean water level (Fig. 7b), and had strong significant correlations with all other hydrology metrics (Table 2), whereas tree basal area showed no significant relationships (Table 2). Total maple tree density and basal area had no significant correlation with hydrologic metrics (Table 2). In contrast, relative metrics for maple tree dominance (density, basal area, and importance value) were all negatively correlated with mean water level and positively correlated with water level standard deviation; however, these correlations, although significant, were moderate to weak (Table 2, Fig. 7c). Despite the decrease in relative maple tree dominance with increased wetness, maple seedling density was positively correlated with mean water level (Table 2). Overall stand richness (across all strata) increased significantly with mean water level (Fig. 7d) and had significant correlations with all other hydrologic metrics (Table 2).

\section{Discussion}

In this work, we explored hydrologic influences on peat depth, microtopography, and forest composition, testing two specific hypotheses. Below, we assess each hypothesis using both transect- and plot-level findings, and then provide recommendations for coupled management and monitoring efforts.

\subsection{H1) Higher and more stable water levels preserve peat depths and microtopographic variation}

At both transect and plot levels, we found strong and positive associations between contemporary water levels and peat depth (Figs. 3a and 7a). These findings confirm our hypothesis that increased wetness preserves peat depths, and are consistent with previous studies demonstrating increased peat oxidation under drained conditions (Galloway et al., 1999; Ewing and Vepraskas, 2006; Drexler et al., 2009). Peat depth also increased with decreasing water level variability (Table 2), but a strong (negative) covariance between mean water level and standard deviation limited our ability to isolate effects of water level variation. We also found increased microtopography at wetter sites with more stable water levels (Fig. 3b, Table 2), possibly due to windthrow (via shallow rooting) and/or spatially variable organic matter accumulation under sustained wet conditions (Ehrenfeld, 1995b; Lampela et al., 2016). Note that our peat depth observations were constrained to one region of GDS (northeast corner), where some of the shallowest depths have been documented compared to depths exceeding $3 \mathrm{~m}$ in other GDS locations (Oaks and Coch, 1973). To our knowledge, however, our work is the first in GDS to link peat depths with contemporary hydrologic regime, thereby highlighting water levels that may preserve peat depths, microtopography, and the carbon storage function valued in GDS and other forested peatlands.

Peat depths and microtopography can be a product of both historical and contemporary hydrologic regimes (Beylea and Bair, 2006). Peat depths result from slow accretion rates (ca. $0.15-0.56 \mathrm{~cm} / \mathrm{yr}$ at GDS; Drexler et al., 2017) and are thus largely a result of historical hydrology (Lichtler and Walker, 1974). However, relationships between contemporary water levels and peat depths can indicate possible hydrologic change (e.g., Wosten et al., 1997). For example, positive correlations suggest that wet sites have been historically wet to sustain peat accumulation. However, for dry sites, a positive correlation suggests either historically dry conditions (i.e., little historical accumulation) or that sites have become drier under contemporary conditions (i.e., loss of peat via oxidation). Further, contemporary water level dynamics can exert primary control on local variation in peat surface elevations (Belyea and Clymo, 2001; Beylea and Bair, 2006). Relationships found here between microtopography and hydrologic regime highlight the influence of contemporary conditions to preserve and potentially enhance hummock and hollow topography. Going forward, coupling observations of hydrologic regime with estimates of both historical and current peat depths may further reveal how contemporary hydrology influences peat preservation and loss.

\subsection{H2) Higher water levels decrease red maple importance and increase overall stand richness}

Hydrologic regime can exert strong controls on wetland vegetation by influencing productivity, tree regeneration, and species composition. More specifically, wetter sites can exclude more facultative tree species (Burke et al., 2005) but also reduce productivity of the obligate wetland species present through anaerobic stress (Vann and Megonigal, 2002). Both the degree of species selection and influence of anaerobic stress vary across species and hydrologic conditions (Angelov et al., 1996).

At both transect and plot levels, we found decreased red maple tree dominance and increased density of other wetland tree species with increased wetness. At the transect level, lower maple dominance in the two wettest transects ( 4 and 5) was evident and significant, whereas there were no statistical differences in maple importance value among the other transects (Fig. 5c). Consequently, plot level analysis yielded rather weak, albeit significant, negative correlations between maple importance value and mean water level, but where decreases at the wettest plots (plots in transects 4 and 5) were distinct (Fig. 7d). Tree species and size class distributions further illustrate this transition in community composition from dry to wet transects, with higher frequencies of obligate and facultative wetland species (sweetbay, swamp tupelo, redbay) at wetter transects (Fig. 4, Table 1). Consequently, stand-level richness significantly increased with wetness at both transect and plot levels (Figs. $5 \mathrm{f}$ and $7 \mathrm{~d}$ ), confirming our overall prediction that contemporary water levels influence vegetation composition.

Our hypothesis of higher stand richness with increased wetness was founded on predictions that wetness decreases maple competition. Decreased relative (but not total) maple tree density and basal area with increased wetness implies more non-maple trees and possible maple stress at wetter sites. Possible stress to maple and other tree species is further supported by increased overall tree density (Fig. 5a) and generally smaller trees at wetter sites (Fig. 4). Higher water levels may reduce maple canopies (i.e., leaf area but not tree density), allowing more non-maple species to compete for light and increasing frequency of other species across strata (Malecki et al., 1983; Vann and Megonigal, 2002). In contrast to our maple tree measurements, we 
found increased density of maple seedlings at wetter sites (Table 2), suggesting potential for continued red maple presence across hydrologic regimes despite previous observations of lower regeneration under wetter conditions (Malecki et al., 1983; Ehrenfeld, 1995a). Continued research is needed to understand stand dynamics and successional patterns of red maple under contemporary hydrologic regimes and if these regimes can be manipulated to reduce maple dominance and increase overall stand richness.

\subsection{Implications for management and restoration}

In drained, forested peatlands, successful restoration can involve three-steps: (1) the removal of post-disturbance forest, (2) hydrologic restoration, and (3) replanting target tree species (Chimner et al., 2017). However, at large spatial scales such as at GDS, forest harvest and replanting may not be feasible, leaving hydrological restoration and subsequent ecosystem response as the principal management approach (Chimner et al., 2017). Our findings highlight hydrology as a potentially effective tool and support current efforts at GDS and other peatlands to manage hydrologic regimes. Specific to GDS, our findings point to future monitoring needs to assess ecosystem response to planned hydrologic change and, in doing so, help adaptively achieve management goals. First, baseline data are required to assess ecosystem response, and indeed one motivation for our study was to provide such data in a GDS location where future restoration was planned. However, our transects were solely in the northeastern corner of GDS, potentially missing other forest communities and different hydrologic regimes, and were limited to one transect per site. Future work could apply similar monitoring approaches and with a more robust sampling scheme at other GDS locations where hydrologic restoration is planned to evaluate vegetative response across the full range of GDS community types. Second, monitoring efforts could directly focus on possible maple stress (e.g., via leaf area measurements) with increased wetness and associated effects to densities and regeneration of other species. Lastly, more work is needed to isolate the effect of contemporary hydrology on peat depths and associated carbon storage. Coupled observations of peat depth and water level dynamics beyond our study domain would better capture the full extent of variation in peat deposits and thus historical hydrologic regimes across GDS.

Peatland drainage is a globally common stress (Cris et al., 2014) expected to continue with growing agriculture demands, particularly in temperate and tropical regions (Rochefort and Anderson, 2017), calling for continued restoration efforts and measurements that can monitor trajectories of ecosystem response. Findings from our study, and those from others (e.g., see review by Kimmel and Mander, 2010), highlight "rewetting" as an effective tool to achieve biodiversity and carbon storage goals. However, ecosystem response likely varies across climatic regions, vegetation species, and the degree of hydrologic change. Consequently, and as we suggest for GDS, monitoring is necessary for informed and adaptive management of hydrologic regimes. Monitoring ecosystem response is a widely recognized, important aspect of successful restoration. However, in addition to baseline characterization, we emphasize the importance of pre-restoration data to guide initial restoration efforts by linking ecosystem attributes and existing hydrologic gradients, and to identify responses (and thus measures of restoration trajectories) to target in subsequent monitoring. Indeed, our work at GDS provides support for current efforts to reduce maple density via rewetting and proposes specific metrics of ecosystem response to monitor over both short (e.g., maple canopy leaf area index) and long terms (e.g., microtopographic variation). Restoration trajectory metrics will vary by system and restoration goals (e.g., from specific floristic assemblages and insect communities to peat accretion rates; Gorham and Rochefort, 2003), but baseline monitoring can help identify and refine responsive measures. Similarly, post-restoration monitoring can be used to develop indicators for future restoration at similar sites (e.g., desirable early indicator species; Gonzalez et al.,
2013), reinforcing the importance of coupled management and monitoring efforts.

Notably, our work is helping to guide a recent collaboration with GDS and the Sebangau National Park in Central Kalimantan, Indonesia. Through a Sister Protected Area Partnership supported by the U.S. Department of Interior's International Technical Assistance Program, staff from GDS and Sebangau have participated in scientific exchanges between the two countries. The partnership was born out of the shared experience and challenges of managing and restoring degraded forested peatlands in the U.S. and Indonesia. The primary goals of the partnership are to: 1) improve understanding of and capacity for peatland management, and 2) enhance hydrological restoration and associated monitoring techniques in forested peatlands (Lowie et al., 2016).

\subsection{Conclusions}

In this work, we explored hydrologic controls on vegetation composition and peat depths to inform ongoing restoration efforts at GDS and other degraded forested peatlands. Results support our predictions that wetter sites have thicker peat, more microtopographic variation, lower red maple importance, and higher stand richness. In doing so, our work highlights key interactions between hydrologic regime and forested wetland structure and function, broadly supporting water management strategies at GDS and other degraded forested peatlands.

\section{Acknowledgements}

This work was funded by the Virginia Tech Department of Forest Resources and Environmental Conservation, U.S. Fish and Wildlife Service Great Dismal Swamp National Wildlife Refuge, and U.S. Geological Survey. ("Any use of trade, product, or firm names is for descriptive purposes only and does not imply endorsement by the U.S. Government.") Special thanks to Ray Ludwig and Will Doran for data collection assistance and Tal Roberts for technical support.

\section{References}

Angelov, M.N., Sung, S.S., Harms, W.R., Kormanik, P.P., Black, C.C., 1996. Long-and short-term flooding effects on survival and sink-source relationship of swampsadapted tree species. Tree Physiol 16, 477-484.

Atkinson, R.B., DeBerry, J.W., Loomis, D.T., Crawford, E.R., Belcher, R.T., Brown, D.A., Perry, J.E., 2003. Water tables in Atlantic white cedar swamps: implications for restoration. In: Atlantic White Cedar Restoration Ecology and Management, Proceedings of a Symposium. Christopher Newport University, Newport News, pp. 137-150.

Beylea, L.R., Bair, A.J., 2006. Beyond "the limits to peat bog growth": cross-scale feedback in peatland development. Ecol. Monogr. 76, 299-322.

Belyea, L.R., Clymo, R.S., 2001. Feedback control of the rate of peat formation. P. R. Soc. Lon. B. Biol. 268, 1315-1321.

Boelter, D.H., 1972. Water table drawdowns around an open ditch in organic soils. J. Hydrol. 15 (1972), 329-340.

Bruland, G.L., Richardson, C.J., 2005. Hydrologic, edaphic, and vegetative responses to microtopographic reestablishment in a restored wetland. Rest. Ecol. 13, 515-523.

Cris, R., Buckmaster, S., Bain, C., Reed, M. (Eds.), 2014. Global Peatland Restoration Demonstrating Success. IUCN UK National Committee Peatland Programme, Edinburgh. http://www.iucn-uk-peatlandprogramme.org/publications/ demonstrating-success/global-demonstrating-success.

Burke, M.K., King, S.L., Gartner, D., Eisenbies, M.H., 2005. Vegetation, soil, and flooding relationships in a blackwater floodplain forest. Wetlands 23, 988-1002.

Carter, V., Gammon, P.T., Garrett, M.K., 1994. Ecotone dynamics and boundary determination in the Great dismal swamp. Ecol. Appl. 4, 189-203.

Chimner, R.A., Cooper, D.J., Wurster, F.C., Rochefort, L., 2017. An overview of peatland restoration in North America: where are we after 25 years? Restor. Ecol. 25, 283-292.

Clarke, K.R., 1993. Nonparametric multivariate analyses of changes in community structure. Aust. J. Ecol. 18, 117-143.

Clymo, R.S., Turunen, J., Tolonen, K., 1988. Carbon accumulation in peatland. Oikos 81 (2), 368-388.

Craft, C.B., Richardson, C.J., 1993. Peat accretion and phosphorus accumulation along a eutrophication gradient in the northern Everglades. Biogeochemistry 22, 133-156.

Curtis, R.O., Marshall, D.D., 2000. Why quadratic mean diameter? technical note. West. J. Appl. For. 15 (3), 137-139.

Dabel, C.V., Day Jr., F.P., 1977. Structural comparisons of four plant communities in the Great dismal swamp, Virginia. Bull. Torrey Bot. Club 352-360.

Daubenmire, R., 1959. A canopy-coverage method of vegetational analysis. Northwest 
Sci. 33, 43-64.

DeBerry, J.W., Atkinson, R.B., 2014. Aboveground forest biomass and litter production patterns in Atlantic white cedar swamps of differing hydroperiods. SE. Nat. 13 (4), 673-690.

Drexler, J.Z., Christian, S.F., Deverel, S.J., 2009. The legacy of wetland drainage on the remaining peat in the Sacramento-San Joaquin Delta, California, USA. Wetlands 29 (1), 372-386.

Drexler, J.Z., Fuller, C.C., Orlando, J., Salas, A., Wurster, F., Duberstein, J.A., 2017. Estimation and uncertainity of recent carbon accumulation and vertical accretion in drained and undrained forested peatlands of the Southeastern USA. J. Geophys. Res.Biogeosci. https://doi.org/10.1002/2017JG003950.

Ehrenfeld, J.G., 1995a. Microsite differences in surface substrate characteristics in chamaecyparis swamps of the New Jersey pinelands. Wetlands 15, 183-189.

Ehrenfeld, J.G., 1995b. Microtopography and vegetation in Atlantic white cedar swamps: the effects of natural disturbances. Can. J. Bot. 73, 474-484.

Ewing, J.M., Vepraskas, M.J., 2006. Estimating primary and secondary subsidence in an organic soil 15, 20, and 30 years after drainage. Wetlands 26, 119-130.

Frost, C.C., 1987. Historical Overview of Atlantic White Cedar in the Carolinas. Atlantic White Cedar Wetlands. Westview Press, Boulder, CO.

Galloway, D., Jones, D.R., Ingebritsen, S.E. (Eds.), 1999. Land Subsidence in the United States. U.S. Geological Survey Circular 1182. U.S. Geological Survey., Reston, VA.

Gammon, P.T., Carter, V., 1979. Vegetation mapping with seasonal color infrared photographs. Photogramm. Eng. Rem. Sens. 45, 87-97.

Golet, F.C., Calhoun, A.K., DeRagon, W.R., Lowry, D.J., Gold, A.J., 1993. Ecology of Red Maple Swamps in the Glaciated Northeast: A Community Profile. United States Fish and Wildlife Service, pp. 170.

Gonzalez, E., Rochefort, L., Boudreau, S., Hugron, S., Poulin, M., 2013. Can indicator species predict restoration outcomes early in the monitoring process? A case study with peatlands. Ecol. Indicat. 32, 3232-3238.

Gorham, E., Rochefort, L., 2003. Peatland restoration: a brief assessment with special reference to Sphagnum bogs. Wetl. Ecol. Manag. 11, 109-119.

Graham, S.A., Craft, C.B., McCormick, P.V., Aldous, A., 2005. Forms and accumulation of soil P in natural and recently restored peatlands-upper Klamath Lake, Oregon, USA. Wetlands 25, 594-606.

Holden, J., Chapman, P.J., Labadz, J.C., 2004. Artificial drainage of peatlands: hydrological and hydrochemical process and wetland restoration. Prog. Phys. Geogr. 28, 95-123.

Kenney, T.A., 2010. Levels at gaging stations. U.S. Geological Survey Techniques and Methods 3-A19.

Kimmel, K., Mander, U., 2010. Ecosystem services of peatlands: implications for restoration. Prog. Phys. Geogr. 34, 491-514.

Kruskal, J.B., 1964. Multidimensional scaling: a numerical method. Psychometrika 29, 115-129.

Lampela, M., Jauhiainen, J., Koskinen, M., Tanhuanpaa, T., Valkeapaa, A., Vasander, H., 2016. Ground surface microtopography and vegetation patterns in a tropical peat swamp forest. Catena 139, 127-136.

Legrand Jr., H.E., 2000. The Natural Features of Dismal Swamp State Natural Area. North Carolina. The Natural History of the Great Dismal Swamp, Omni, Madison, Wisconsin, pp. 41-50.

Levy, G.F., 1991. The vegetation of the Great dismal swamp: a review and an overview. Va. J. Sci. 42, 411-418.

Levy, G.F., Walker, S.W., 1979. Forest Dynamics in the Dismal Swamp of Virginia. The Great Dismal Swamp. Old Dominion University Research Foundation, Inc.

Lewis, I.F., Cocke, E.C., 1929. Pollen Analysis of Dismal Swamp Peat. Elisha Mitchell Scientific Society.

Lichtler, W.F., Walker, P.N., 1974. Hydrology of the Dismal Swamp. Geo. Surv. - Water Resources Division, VA-NC 74-39.
Lowie, C., Wurster, F.C., Lawlor, S., Riley, J., Gunawan, A., Nugraheni, N., 2016. A Partnership between Two Protected Peatlands: Great Dismal Swamp National Wildlife Refuge, Virginia, USA and Sebangau National Park, Central Kalimantan, Indonesia [abs]: $15^{\text {th }}$ International Peat Congress, Abstracts. Sarawak, Malaysia.

Malecki, R.A., Lassoie, J.R., Rieger, E., Seamans, T., 1983. Effects of long-term artificial flooding on a northern bottomland hardwood forest community. For. Sci. 29, 535-544.

Mitsch, W.L., Gosselink, J.G., 2007. Wetlands. John Wiley \& Sons, Inc, Hoboken.

Oaks, R.Q., Coch, N.K., 1973. Post-miocene Stratigraphy and Morphology, Southeastern Virginia. Commonwealth of Virginia, Division of Mineral Resources.

Oksanen, J., Blanchet, F.G., Friendly, M., Kindt, R., Legendre, P., McGlinn, D., Minchin, P., O'Hara, R.B., Simpson, G.L., Solymos, P., Stevens, M.H., Szoecs, E., Wagner, H., 2017. Vegan: Community Ecology Package. version 2.4-2.

Osbon, C.C., 1919. Peat in the dismal swamp, Virginia and North Carolina. Contrib. Econ. Geol. Bull. 711, 4.

Ott, C.A., Chimner, R.A., 2016. Long-term peat accumulation in temperate forested peatlands (Thuja occidentalis swamps) in the Great Lakes region of North America. Mires Peat 18, 1-9.

Parish, F., Sirin, A., Charman, D., Joosten, H., Minayeva, T., Silvius, M., Stringer, L., 2008. Assessment on Peatlands, Biodiversity and Climate Change: Main Report. Global Environment Centre, Kuala Lumpur and Weltands International, Wageningen, pp. 177.

Phipps, R.L., Ierley, D.L., Baker, C.P., 1979. Tree Rings as Indicators of Hydrologic Change in the Great Dismal Swamp, Virginia and North Carolina. US Geological Survey, Water Resources Division.

R Core Team, 2016. R: a Language and Environment for Statistical Computing. R Foundation for Statistical Computing, Vienna, Austria.

Reddy, A.D., Hawbaker, T.J., Wurster, F., Zhu, Z., Ward, S., Newcomb, D., Murray, R., 2015. Quantifying soil carbon loss and uncertainty from a peatland wildfire using multi-temporal LiDAR. Remote Sens. Environ. 170, 306-316.

Rochefort, L., Anderson, R., 2017. Global peatland restoration after 30 years: where are we in this mossy world? Restor. Ecol. 25, 269-270.

Sleeter, R., Sleeter, B.M., Williams, B., Hogan, D., Hawbaker, T., Zhiliang, Z., 2017. A carbon balance model for the Great Dismal Swamp ecosystem. Carbon Balance Manag. 12. https://doi.org/10.1186/s13021-017-0070-4.

Usup, A.Y., Hashimoto, H., Takahashi, H., Hayasaka, H., 2004. Combustion and thermal characteristics of peat fire in tropical peatland in Central Kalimantan, Indonesia. Tropics 14, 1-19.

Turetsky, M.R., Benscoter, B., Page, S., Rein, G., van der Werf, G., Watts, A., 2015. Global vulnerability of peatlands to fire and carbon loss. Nat. Geosci. 8, 11-15.

van der Valk, A.G., 1981. Succession in wetlands: a Gleasonian approach. Ecology 62, 688-696.

Vann, C.D., Megonigal, J.P., 2002. Productivity responses of acer rubrum and taxodium distichum seedlings to elevated CO 2 and flooding. Environ. Pollut. 116, S31-S36.

Vivian-Smith, G., 1997. Microtopographic heterogeneity and floristic diversity in experimental wetland communities. J. Ecol. 71-82.

Watts, A.C., Kobziar, L.N., 2013. Smoldering combustion and ground fires: Ecological effects and multi-scale significance. Fire Ecol. 9, 124-132.

Whitehead, D.R., 1972. Developmental and environmental history of the dismal swamp. Ecol. Monogr. 42, 301-315.

Whitehead, D.R., Oaks, R.Q., 1979. In: Kirk Jr.P.W. (Ed.), Developmental History of the Dismal Swamp. The Great Dismal Swamp. University of Virginia Press, Charlottesville, pp. 25-43.

Wosten, J.M., Ismail, A.B., Van Wijk, A.M., 1997. Peat subsidence and it's practical implications: a case study in Malaysia. Geoderma 78, 25-36.

Wust-Galley, C., Mossinger, E., Leifeld, J., 2016. Loss of the soil carbon storage function of drained forested peatlands. Mires Peat 18, 1-22. 